\title{
Turkish Preschool Children's Pragmatic Competence on Apologies: The Influence of Sociolinguistic Factors and Contextual Variables*
}

\author{
Özge Gül Zerey ${ }^{1}$, Hatice Sofu ${ }^{2}$ \\ ORCID: ${ }^{10000-0002-8633-9296, ~}{ }^{2} 0000-0002-0436-5360$ \\ ${ }^{I}$ Mersin University, School of Foreign Languages, Mersin \\ ${ }^{2}$ Çukurova University, Department of English Language Teaching, Adana \\ ${ }^{1}$ ozgezerey@mersin.edu.tr, ${ }^{2}$ hasofu@cu.edu.tr
}

(Received 18 June 2020; Accepted 30 December 2021)

\begin{abstract}
This study explores Turkish preschool children's pragmatic competence with regard to their apology realization patterns. Children's metapragmatic knowledge of apologies was tested and two different age groups $(4 ; 0-4 ; 11$ and $5 ; 0-6 ; 0)(\mathrm{N}=100)$ were compared to trace possible developmental trends with increasing age in terms of complexity, variety and type of strategies they utilized. Additionally, all the children were grouped according to gender in order to detect the potential effect of this factor on children's apologizing behaviors. Finally, the range of children's socio-pragmatic skills was evidenced by tracing their sensitivity in their strategy usage to the severity of the offense as a contextual variable which has a potential effect on speakers' manner of apologizing. Eight offence scenarios were designed and implemented in the form of Oral Discourse Completion Task (ODCT). The responses were transcribed and phrases for apologizing were classified into categories. The results indicated similarities and differences when compared to adult-usage and children's tendencies in other languages.

Keywords: pragmatic competence, the speech act of apology, children's sociopragmatic skills
\end{abstract}

"This study has been supported by TUBİTAK's (The Scientific and Technological Research Council of Turkey) scholarship program for graduate students. 


\section{Anaokuluna Giden Türk Çocukların Özür Dileme Söz Eylemine ilişkin Edimsel Yeterlilikleri: Sosyo-linguistik Faktörlerin ve Bağlamsal Değişkenlerin Etkisi}

ÖZ: Bu çalıșma anaokuluna giden Türk çocukların özür dileme söz eylemini gerçekleştirme kalıplarına ilişkin edimsel yeterliliklerini araştırmaktadır. Öncelikle çocukların özür dileme söz eylemine ilişkin meta-pragmatik bilgileri test edilmiş ve sonrasında iki yaş grubu $(4 ; 0-4 ; 11$ ve $5 ; 0-6 ; 0)(\mathrm{T}=100)$ yaşla beraber ortaya çıkan gelişimsel özellikler açısından kıyaslanmıştır. Ayrıca, yaş gözetilmeksizin, tüm çocuklar cinsiyetlerine göre yeniden gruplandırılmış ve cinsiyet faktörünün çocukların özür dileme kalıpları üzerindeki etkisine bakılmıştır. Son olarak, çocukların sosyopragmatik becerileri, konuşucuların özür dileme davranışları üzerinde etkili olduğu bildirilen bağlamsal değişkenlerden biri olan "suçun şiddeti”ne duyarlılıkları ile ölçülmüştür. Suç içeren sekiz senaryo yukarıda bahsedilen bağlamsal parameter etrafında şekillendirilerek hazırlanmış ve Sözlü Söylem Tamamlama Testi formatında uygulanmıştır. Daha sonra bu yanıtların dökümü çıkarılmış, çalışmada kullanılmak üzere seçilen taksonomiye dayanarak sınıflandırılmış ve istatiksel olarak analiz edilmiş̧ir. Sonuçlar, yetişkin kullanımı ve diğer dillerdeki çocuk kullanımları ile kıyaslandığında benzerlik ve farklılıklar göstermektedir.

Anahtar Sözcükler: edimsel yeterlilik, özür dileme söz eylemi, sosyopragmatik beceriler

\section{Introduction}

Researchers have paid much attention to children's development of communicative intent through the analysis of children's everyday speech in order to find out the type of functions they express in their language. Speech act analysis has been commonly used to characterize this kind of development (Cameron-Faulkner, 2014).

As Ninio and Snow (1996, p. 13) claim, learning how to use speech for performing these "social-communicative acts" is a primary developmental task for children, since it requires social and conceptual readiness. Children need to have sufficient verbal skills as well as the mastery of several socio-cognitive capacities. In this regard, the authors argue that learning in which situation it is appropriate to use direct demand and in which a polite request necessitates children's having knowledge about the meaning of demands and requests. Their abilities to verbally express communicative intentions are directly related to developments in their cognitive abilities, social understanding, and linguistic skills as well (Snow, Pan, Bailey \& Herman, 1996). From a developmental perspective, children's speech acts are investigated to identify the types of communicative intents they are able to express at various ages, and the extent of 
the linguistic means they utilize to convey these intents at various periods in the course of development (Ninio \& Snow, 1996).

In recent years, as one of the speech acts, apologies have gained more popularity as an area of research in various fields compared to others (Cohen, 1996) due, mainly, to their pervasive existence in society (Cordella-Masini, 1989). They are regarded as "face-threatening acts" in that the speaker acknowledges his/her own quilt and therefore threatens his/her own positive face (Brown \& Levinson, 1987). As "social tools", apologies are resorted to redress damaged relations and "mitigate loss of face" (Ely \& Gleason, 2006:599). However, unlike such politeness terms as "thanks" and "please", the situations that necessitate apologies are not routinized and uniform (Ely \& Gleason, 2006, p. 603) and children's realization of apologies reflects their awareness of violation of a social rule and their concern for people's face wants (Chang, 2018). In this regard, children's gaining competence in the use of apologies is considered as a major developmental endeavour in the overall socialization process (Ely \& Gleason, 2006) during which children get into various kinds of interactions, and hence gain an opportunity to get input on the social and cultural norms particular for that language community (Schieffelin and Ochs, 1986). This can be termed as "pragmatic socialization", which refers to "the ways in which children are socialized to use language in context in socially and culturally appropriate ways" (Blum-Kulka, 1997, p. 3).

Much of our information on children's metapragmatic knowledge on apologies comes from developmental studies in the field of psychology. While some of them have focused on children's evaluations of the wrongdoer (e.g., Darby and Schlenker, 1982), some have concerned with their inferences about the way the offended party is affected by an apology (see Smith et al., 2010). The general conclusion drawn from these studies is that even four-year-old children are aware that an apology will help to make the offended feel better.

By compiling several findings from research in the field of experimental psychology, Meier (2004, p. 4) provides a developmental model of apology, and states that although even preschool children possess a basic perception as to responsibility and its consequences and adjust excuses and justifications depending on the types of offence, there are several dimensions of apologies that indicate changes as children grow up like "making amends, externalizing causes for a wrongdoing, providing more elaborate apologies". It is clear that as children grow older, the developments in their perceptions contribute to their production of apologies making them more sophisticated rather than being simple in form.

In Kampf and Blum-Kulka's (2007, p. 12) terms, successful performance of these remedial acts requires choosing the appropriate form and complying with the fundamental felicity conditions as well. Equally important, for a complete pragmatic competence, in addition to the acquisition of essentials of the remedial behavior, children must also be cognizant of the existence of multiple forms and functions of the act. Since apologies include a certain degree of complexity, it is 
not surprising to expect developmental changes in children's understanding and using apologies at different ages (Smith, 2009).

\section{Aim of the Study}

As Küntay et al. (2014) state, so far, researchers' investigations on communicative acts have been limited to particular speech acts, namely directives (e.g., requests, commands, and orders). Thus, further scrutiny is needed to find out unrevealed details related to children's productions of other speech acts such as apologies as well.

Up till now, apologies have become well-established area of research especially in terms of adult-usage thanks to various studies in many languages including Turkish (e.g. Hatipoğlu, 2003; Özyıldırım, 2010; Çetinavcı, 2012), mostly with cross-cultural perspective following the seminal work of BlumKulka et al.'s (1989) Cross-cultural Speech Act Realization Project (CCSARP) which has aimed to establish similarities and variations among languages with regard to realisation patterns of apologies and requests. Additionally, the potential effect of several contextual parameters on adults' apologizing behaviors has been adequately explored. However, the same does not hold true for children's apologies as, to the best of our knowledge, there are relatively few studies in a limited number of languages (English: see Ely \& Gleason, 2006; Hebrew: Kampf \& Blum-Kulka, 2007; Kurdish and Persian: Sadeghi, 2013; and Mandarin Chinese: Chang, 2016). In this respect, it would be enlightening to uncover Turkish children's metapragmatic knowledge about apologies and the linguistic forms and strategies they employ to realize this act, which may provide a baseline to make cross-linguistic and cross-cultural judgments on children preferences in addition to the comparisons with the adult-usage.

Relying on what has been included under the frameworks of communicative and pragmatic competence in the available empirically well-formulated models, in the present study we regard pragmatic competence as comprising of pragma linguistic and socio-pragmatic skills. In this sense, children's pragmatic competence will be assessed in terms of their metapragmatic knowledge about the speech act of apology. Additionally, their pragma linguistic skills will be tested by their knowledge of various forms to realize apologies and lastly, their socio-pragmatic skills will be explored by tracing their ability to tailor their manner of apologizing depending on the contextual variable of severity of the offence. The queries addressed throughout the study are as follows:

1. Do the children aged between $4 ; 0$ and $6 ; 0$ display metapragmatic awareness related to correct way of using language for apologizing?

2. What are the characteristics of 4-6-year-old children's apology strategies in terms of complexity, variety, and types?

3. Do the children's preferences of apologizing strategies display change in terms of gender? 
4. Do the children's preferences of apologizing strategies display change across the severity of the offence as a contextual factor?

\section{Methodology}

\subsection{Setting and Participants}

The study was conducted with preschool children at a state preschool in Turkey. The school was chosen via convenience sampling, which is "a non-random sampling technique that involves selecting what is immediately available" (Walliman, 2011, p. 167). After getting the official permission from the Ministry of National Education to collect the data at a specific preschool, a consent form and a brief description of the data collection procedure were sent to the parents of the children and they all signed the form. Upon receiving the consent form, the parents were sent a demographic information form which asks for such information as their level of education and their child's date of birth.

There were two age groups at the school; the first one was the morning group which comprises of children aged between $4 ; 0$ and $4 ; 11$, and there were four morning classes each having 25 children. The second one was the afternoon group including children between the ages of 5;0 and 6;0. Similarly, there were four afternoon classes having 25 children in each. Nearly 13 children were chosen randomly from each class by their teachers to participate in the study. Therefore, the participants of the study were 100 children aged between 4;0 and 6;0 who were all monolingual and native speakers of Turkish. They were grouped into two (Group I: 4;0-4;11; Group II: 5;0-6;0) according to their age. The profile of the participants is presented in Table 1 below.

Table 1. Profile of the participants

\begin{tabular}{lcc}
\hline Age Range & $\mathrm{N}$ & Mean Age \\
\hline $4 ; 0-4 ; 11$ & 48 & $4 ; 5$ \\
$5 ; 0-6 ; 0$ & 52 & $5 ; 8$ \\
Total & 100 & \\
\hline
\end{tabular}

As it is apparent in Table 1, there are 48 children in the younger group and 52 in the older one, which makes totally a hundred. While the mean age is $4 ; 5$ for the first group, it is 5;8 for the second one. All the participant children, irrespective of age, were then regrouped depending on the social variable of gender in order to investigate the potential effect of such independent variable on children's overall manner of apologizing. The details are described in Table 2 below: 
Table 2. Overall profile of participants based on gender

\begin{tabular}{lccc}
\hline Age Range & \multicolumn{3}{c}{ Gender } \\
\hline & F & & M \\
\cline { 2 - 4 } $4 ; 0-5 ; 8$ & 51 & & 49 \\
Total & & 100 & \\
\hline
\end{tabular}

Table 2 illustrates the number of children in each group. Accordingly, the whole corpus consists of 49 male and 51 female children, which indicates that the gender distribution is nearly balanced.

\subsection{The Rationale for the Data Collection Tool}

Among the tools in the area of pragmatics research, Discourse Completion Test (DCT) is a widely used questionnaire which requires subjects to give written responses to described situations in given scenarios with such details as the setting and the social distance between interlocutors (Bardovi-Harlig \& Hartford, 2005). However, as Kasper (2000) points out, it is not always suitable to employ written DCTs especially when the subjects are young children or low proficiency L2 learners, since they are not capable of reading and providing written responses.

To date, children's apologies have been studied mainly by using experimental methodologies (Kampf \& Blum-Kulka, 2007) with hypothetical scenarios (Schleien et al., 2010) instead of using observatory methods since it is not always certain that the speech act under study will emerge throughout the observation. For very young children, Kasper (2000) suggests using the Cartoon Oral Production Task (COPT) developed by Rose (2000). This instrument comprises a series of cartoons and a familiar scenario is depicted in each cartoon. In addition, it does not require children to read or fill in a questionnaire, which is, naturally, impossible for this age group. That is, it provides an opportunity to elicit oral responses rather than written ones.

Hence, taking into account the age of the participants in the present study, who cannot either read or write, it was decided to utilize Oral Discourse Completion Task (ODCT) accompanied by pictures related to scenarios similar to Rose's (2000) COPT. The scenarios were designed in the form of open ODCTs in which a situation was described, and participants were asked for their response in spoken form. The scenario construction process is explicated in the following section.

\subsection{Development of the Scenarios}

As stated by Rose (2009), the scenarios in the questionnaires employed in pragmatic research have mostly been the product of the researchers' imagination. 
Instead, he suggests using a form of exemplary generation in which one or two examples of the speech act under study are presented and administered to different groups of students or learners who are similar to the target population. Next, they are asked to evaluate them for likelihood, relevance, and context variables. This method of scenario generation provided a basis to the researcher for taking similar steps in designing scenarios.

As the first step, the researcher scanned the relevant literature for the characteristics of preschool children and research on preschool children's conflicts to obtain a scenario pool to design situations that are similar to the ones children encounter in their daily lives. The scenarios in the DCTs used in the studies investigating apology strategies of teenage or adult subjects were kept out of search, since such situations as bumping into a lady, a student's borrowing her professor's book, or a university professor's not keeping his promise to return the term paper of a student are not prevalent in child discourse.

Literature review process has indicated that preschool children are highly energetic, enjoy playing games and with toys. In addition, verbal or physical aggression accompanied by crying or anger, object and territorial disputes emerged as the most potential causes of conflicts among the preschool-aged children (Sackin \& Thelen, 1984). For instance, Schleien et al. (2010, p. 175) examined the findings from many hours of observation of siblings when they were younger and older, which included over 3500 sibling fights. For coding the data, they classified transgressions occurred throughout the observation as physical harm, verbal harm, and right violations providing example behaviors for each.

The examination of the relevant literature mostly in the field of social psychology also revealed that these types of offence were the main cause of conflicts among children. Therefore, it was decided to design scenarios depending on Schleien et al.'s classification of transgression types. The scenarios were developed taking into account the example behaviors in the offence categories and manipulated depending on the contextual variable of severity of the offence, which has been regarded as one of the key parameters that determine subjects' apology realisation patterns (Olshtain, 1989; Holmes, 1990; Rose, 2000). In this study, the severity of the offence was treated as binary-valued: either high [H], or low [L].

In the third phase, the researcher prepared 10 scenarios and put them on a separate assessment scale as suggested by Rose (2009). However, different from Rose, instead of children, as they cannot read or write, 18 teachers working at different preschools were asked to assess the scenarios for the likelihood of occurrence, relevance, and context variables. They were asked to perform two actions: (1) mark the given scenarios as either High or Low in terms of severity of the offence, and (2) indicate their likelihood of occurrence in a typical preschool classroom on a Likert Scale. After that, the responses of those teachers were entered into the Excel and the scenarios with the highest mean values were 
chosen to be included in the ODCT while the ones with the lowest mean values were excluded.

The resulting version of ODCT contains totally eight scenarios: four with high severity and four with low. There were also four distractor scenarios, designed as controls used to distract children's attention from the speech act in question. At the same time, distractors help to prevent children from providing routinized responses because of gaining familiarity with the task itself. The variables around which the scenarios were developed and manipulated are presented with a brief description of the situations in Table 3 below:

Table 1. Distribution of contextual variables of the scenarios employed in the study

\begin{tabular}{lc}
\hline Situation & $\begin{array}{c}\text { The severity of the } \\
\text { Offence }\end{array}$ \\
\hline 1. The child slaps his/her friend & High \\
2. The child pushes his/her friend & Low \\
3. The child mocks his/her friend & High \\
4. The child shouts at his/her friend & Low \\
5. The child breaks his/her friend's toy & High \\
6.The child scratches his/her friend's drawing & Low \\
7. The child imitates his/her teacher & -- \\
8. The child gets cross with his/her teacher & -- \\
\hline
\end{tabular}

As shown in Table 3, two scenarios were developed for each type of offence; one with low severity and one with high, which was made possible by making slight modifications in the content of the scenarios. And two scenarios for child-toteacher offences. For instance, in one of the apology scenarios with physical harm, while two children are playing a game, one of them gets angry with the other and slaps his/her friend; whereas in the other, the child gets angry and pushes his/her friend in a game. Similarly, while one of the scenarios of verbal harms with a high degree of offence depicts a child who mocks his/her friend and doesn't let him play with them, in the other with a low degree of harm, the child shouts at his/her friend while they are playing a game.

Furthermore, at least three cartoon-style pictures were prepared for each scenario in order to help the children better understand the situations, interpret them more easily, and visualize them in their minds as suggested by Cohen (2004). The characters in each story were matched to the participant child's sex. In other words, the gender of the addressee was not taken as a variable: the scenarios are experienced in same-sex dyads. In addition, as the physical setting can influence the perception of the seriousness of an offence (Blum-Kulka \& Olshtain, 1984), the setting for each situation was the same; namely children's classroom in the preschool and the offences committed by the children always 
result in the addressee's (the child's best friend or classmate) crying or feeling very upset/unhappy. The addressee's feelings were kept constant, since they can affect the transgressor's apologetic behavior (Smith et al., 2010).

\subsection{Data Collection Procedure}

To gather the data, each child was presented eight scenarios and four distractors which were the situations that require children to produce the speech acts of suggestion, refusal, thanking, and request. The researcher worked with each child in a quiet room at the preschool, which has been reserved for meetings with children's parents together with their children. Therefore, the participant children were familiar with the room. During the data collection, the necessary precautions were taken to avoid stating the object of the research, since this could have pre-conditioned the outcomes of the study. Thus, they were told that they would look at some pictures and hear stories about them.

The situations in the scenarios were presented with at least three pictures, each narrating one part. At the end of each scenario, the child committed either a serious or a minor offence which required him/her to apologize to his/her friend or teacher. The scenarios were clearly described to each child by the researcher paying extra attention to using the same tone of voice and intonation. The social and contextual information such as the setting, the relationship between the participant child and the other child, the offence he/she commits, and the result of the offence are stressed when reporting the situations to the informants since these factors have an influential role in speakers' choices of apology strategies as stated in the related literature. Each child heard the same questions following each scenario. The elicitation questions were as follows: "What should you do in this situation? What should you say? How do you do this? and What do you say to him/her? What else would you say?". In addition, each child was allocated the same duration of time following the researcher's questions and if they were silent after the questions, it was supposed that they did not fully understand the scenario and it was repeated in a clearer way. The conversation between the researcher and the participant child was recorded via mobile phone.

The process always began with a brief warm-up in which includes asking about their names, ages, and brothers or sisters, etc. In this way, they would feel that they were making a conversation with the researcher and they were not part of a test. Following this, the researcher asked them whether they loved to look at pictures and then when they said "yes", she started to show the pictures and describe the situations in the scenarios.

The scenarios were presented to each child in the same order to eliminate any effects that will stem from different ordering. The data collection process lasted for approximately fifteen minutes with each child. The whole data collection process lasted for one and a half months with the researcher's everyday presence at the preschool. 


\title{
3.5 Data Analysis
}

After the data collection process was completed thoroughly, the taperecorded data were transcribed by the researcher using standard orthography. As the next step, the categories of apology strategies offered or utilized by the researchers in the related field were examined to accommodate all the semantic formulas emerged in the corpus. The final version of the coding taxonomy adapted mainly from Olshtain and Cohen (1983) was prepared and the apologies elicited through ODCT were analysed as consisting of a sequence of semantic formulas as well as single strategies in order to explore the complexity of children's apology strategy patterns, which was examined in terms of the combination patterns of strategies and the total number of strategies employed. Accordingly, for single strategies, all the main and sub-strategies included in the taxonomy were given numbers ranging from 1 to 22 . Secondly, the transcribed corpus was investigated and all the strategy combinations produced were specified and written on a separate sheet. As a result, the corpus yielded two- and three-strategy combinations including combination categories produced with both main and sub-strategies. These categories were given numbers as well starting from 23. An example coding is described below:

\section{Extract 1: Verbal Harm/ Low severity \\ CH63: Üzgünüm.}

[An Expression of Regret]

I'm sorry.

\author{
Extract 2: Verbal Harm/ High severity \\ CH82: Özür dilerim. Kazayla yaptım. \\ [Offer of Apology+Lack of Intent] \\ I apologize. I did it by mistake
}

\author{
Extract 3: Right Violation/ High severity \\ CH81: Özür dilerim. Bir daha yapmayacağım. \\ İstersen tamir edebilirim. \\ [Offer of Apology+A Promise of Forbearance+Offer of Repair] [55] \\ I apologize. I won't do this again. I can repair it if you like.
}

Here, in the first example, the child responded to an offence situation by using a single strategy; namely an expression of regret, and it was coded with number 2. On the other hand, in the second example, there was a preference for employing a two-strategy combination by combining an offer of apology with an expression of lack of intent, which was coded with the number 34. Finally, the last extract presents an example of three-strategy combination, which was given the number 55 while coding the data into categories. 
Following the enumerating, the transcribed strategies were coded based on these numbers and they were entered into SPSS in order to find out how frequently the single, two- and three-strategies were used by the participants and which strategies or strategy combinations were preferred more frequently. In addition, in order to examine whether the difference in frequencies was statistically significant, the log-likelihood (LL) test was performed. Besides, an additional reason to use this test was to normalize the data. That is, since the number of the participants in each age group and also in each variable group (gender, preschool education, etc.) was not equal, we needed to handle the data in a single data outline. This test is used to measure statistical significance, which is similar to the Pearsons' Chi-square measure in this respect. The LL test is generally used in corpus analysis and considered as a reliable alternative to the Pearsons' Chi-square in the statistical analysis of texts (Dunning, 1993). The test is also a common type of measurement in the field of pragmatics research and suitable for comparing the tendencies of pragmatic choices of two groups (see Babanoğlu, 2014; Can and Yakut, 2018). Similar to the statistical methods utilized in the field of language acquisition, in this test, word frequencies are regarded as weighted over two different corpora and the obtained LL value is similar to the p-value obtained through Pearsons' Chi-square (McEnery et al., 2006). Table 4 illustrates the taxonomy utilized in the study.

Table 2. Taxonomy of apology strategies

\begin{tabular}{l} 
Strategies \\
\hline A. Explicit Expression of \\
Apology/Illocutionary Force \\
Indicating Devices (IFIDs) \\
an offer of apology \\
An expression of regret \\
A request for forgiveness \\
*B. Intensification within an offer \\
of apology \\
1. with adverbials \\
C. An explanation or account \\
D. An Acknowledgement of \\
Responsibility \\
Accepting the blame
\end{tabular}

Example

A. Explicit Expression of

Apology/Illocutionary Force

Indicating Devices (IFIDs)

an offer of apology

I apologize. / I apologize for shouting at

you.

Özür dilerim. / Sana bă̆ırdı̆̆ım için özür

dilerim.

I'm sorry / I felt sorry

Üzgünüm / Üzüldüm

Excuse me. / Forgive me.

Affedersin. / Beni affet.

I am very sorry.

Çok özür dilerim.

I didn't know that it was yours.

Senin olduğunu bilmiyordum.

I wish I hadn't mock on you and shout at you/ 
Expressing self-deficiency

Justifying the hearer

Expressing a lack of intent

Concern for the hearer

$* * \mathrm{E}$. An offer of repair

1. direct

2. indirect

F. A promise of forbearance

G. ***No Apology

Blaming others

Downgraders and self-defense

Minimizing the degree of offence

Denial of fault

Expression of Indifference

H. Others

$* * * * 1$. Alerter

$* * * * * 2$. Softeners
I admit that I pushed you.

Keşke seninle dalga geçmeseydim, sana bağırmasaydım. İttiğimi Kabul ediyorum.

Unutmuşum.

I had forgotten about it.

[1]You are right to be angry/Kızmaya hakkın var ${ }^{1}$

It happened unintentionally. /I didn't want to do that.

Istemeden oldu. / Böyle yapmak

istememiştim.

Get well soon / Geçmiş olsun

I will draw you a new picture.

Sana yeni bir resim yaparim.

Let's play a game instead.

Onun yerine oyun oynayalim.

I promise I won't do this again/I will be careful about my mistakes.

Bir daha yapmayacă̆ım söz / Hatalarıma dikkat ederim.

We won't let them break it. (for the toy)

Kırmalarına izin vermeyeceğiz.

Don't worry!

Üzülme!

Bir şey olmaz.

[2] It isn't my fault that it fell down

Onun düşmesi benim hatam değil

[3] I don't care/I don't think so.

Umrumda değil / Ben öyle düşünmüyorum

My teacher/My friend

Öğretmenim /Arkadaşım

I love you too much/My dear friend

Seni cok seviyorum / Canım arkadașım

*taken from Blum-Kulka and Olshtain (1984)

**classified into two sub-categories by the researcher

*** taken from Karsan (2005)

$* * * *$ taken from Chang (2016)

$* * * * *$ new category added by the researcher

${ }^{1}$ These examples are taken from different taxonomies used in studies conducted in Turkish. 


\section{Results and Discussion}

\subsection{Children's Metapragmatic Knowledge on Apologies}

With 12 scenarios manipulated according to severity degree of the offenses, the first aim was to test whether children were aware that the situations which cause physical or emotional damage to a person necessitate an apology. In this respect, their answer to the first question (What should you say in this situation?) after each scenario was described would also demonstrate their ability and knowledge to distinguish among several different speech acts as each is used in different social contexts with different functions for different purposes. The analysis of their responses was actualized in terms of whether the responses included such statements as "I should apologize" or not. The findings are presented in the table below:

Table 5. Distribution of responses related to metapragmatic knowledge of apologies

\begin{tabular}{lcccc}
\hline Responses & $4 ; 0-4 ; 11$ & $(\mathrm{n}=48)$ & \multicolumn{2}{c}{$5 ; 0-6 ; 0$} \\
& $\mathrm{f}$ & $\%$ & $\mathrm{f}$ & $\%$ \\
\hline & & & & \\
I need to apologize & 384 & 100 & 416 & 100 \\
\hline
\end{tabular}

According to the findings, children, irrespective of their age, displayed the knowledge of using "apology", for the transgression scenarios presented to them, discriminating the offence scenarios from the ones that necessitates thanking, suggestion or a polite request.

This shows that children, between the age of 4;0 and 6;0, are cognizant of the remedial function of apologies. To be more precise, they perceive apologies as such acts that have the function of redressing the transgressions and providing reconciliation. In this sense, this finding may also reveal that they have the proper social and cognitive capacities to comprehend what an apology is and what function it serves. As stated by Meier (2004, p. 4), apology production is dependent on "cognitive maturation" which is accompanied by the changes related to "perceptions of responsibility and intentionality..." This finding is in agreement with what has been reported in Kampf \& Blum-Kulka's (2007, p. 6) study in which the rich variety of apology strategies utilized by 4-6-year-old children urged the researchers to state that "acquisition of remedial competencies for face management" is an early accomplishment. 


\subsection{Characteristics of Children's Apologies}

The second research question aimed to find out the characteristics of 4-6-yearold children's apology strategies in terms of complexity, variety and types. The results can be traced in Table 6 below.

Table 6. Observed frequencies and LL ratios of total strategies across the two age groups

\begin{tabular}{lccccc}
\hline Complexity of patterns & $\begin{array}{c}(4 ; 0-4 ; 11) \\
\mathrm{f}(\mathrm{O} 1)\end{array}$ & $\begin{array}{c}(5 ; 0-6 ; 0) \\
\mathrm{f}(\mathrm{O} 2)\end{array}$ & $\begin{array}{c}\text { Total } \\
\mathrm{f}\end{array}$ & LL & Sig. \\
\hline $\begin{array}{l}\text { Single Strategy } \\
\text { Two-strategy }\end{array}$ & 157 & 129 & 286 & 5,44 & $\mathbf{+ 0 , 0 2 0}$ \\
$\begin{array}{l}\text { Combinations } \\
\text { Three-strategy }\end{array}$ & 194 & 247 & 441 & 2,85 & $-0,091$ \\
$\begin{array}{l}\text { Combinations } \\
\text { Total }\end{array}$ & 33 & 40 & 73 & 0,23 & $-0,632$ \\
\hline
\end{tabular}

$\mathrm{f}=$ raw frequency of each category

O1: Observed frequency 1

$\mathrm{O} 2$ : Observed frequency 2

+ indicates overuse in $\mathrm{O} 1$ relative to $\mathrm{O} 2$

-indicates underuse in $\mathrm{O} 1$ relative to $\mathrm{O} 2$

The analysis displayed in Table 6 above revealed a higher employment rate of single strategies in the corpus of the younger group. The usage indicated a decrease as children got older and the statistical analysis pointed at a significant difference $(\mathrm{p}<.05)$. Thus, it seems that children become more prone to employ multiple strategy patterns to mitigate their offences with increasing age. This can be attributable to the developments in their perceptions on responsibility taking following an offence in addition to the developments in their linguistic knowledge and skills. This finding is consistent with what was found by Darby and Schlenker (1982) who concluded that older children (9-12-year-olds) judge more elaborate apologies as more effective to express greater regret subsequent to a transgression compared to younger ones (5-year-olds).

When it comes to the multiple strategy use, both groups were observed to mainly prefer two-combination strategies while expressing their remorse. However, the use of two- and three-combination strategies was found to be higher in the older group although the difference was not statistically verified (p>.01). This finding matches with that of Chang's (2016) who found a developmental pattern in the complexity of strategies with the youngest group's using mainly single or two-strategy combinations contrary to older ones whose corpus consisted mainly of two-, three-, four-, five-, and six-strategy combinations. 
Overall, the higher employment of multiple strategies over standalone usage (single strategies) in both age groups stands in a complete agreement with the outcomes drawn from teenage or adult preferences in various languages (see Demeter, 2006; Holmes, 1990; Vollmer \& Olshtain, 1989).

The following excerpts, emerged in the present data, exemplify the single, two- and three-strategy usage as a response to a variety of offence situations:

\section{Examples from the data}

Extract 4: Physical harm/ High severity

CH14: Sana vurduğum için özür dilerim. [Of. Ap.]

I apologize for hitting you.

Extract 10: Verbal harm/ Low severity

CH43: Özür dilerim. Bir daha yapmak istemiyorum.[Of. Ap.+Promise] I apologize. I don't want to do this again.

\section{Extract 18: Right Violation/ High severity}

CH81: Özür dilerim. Bir daha yapmayacağım. İstersen tamir edebilirim. [Of. Ap.+Promise +Repair]

I apologize. I won't do this again. I can repair it if you like.

The results regarding the mostly used types of single strategies are illustrated in the table below:

Table 7. Observed frequencies and LL ratios of basic apology strategies across the two age groups

\begin{tabular}{lcccc}
\hline Strategy Type & $\begin{array}{c}(4 ; 0-4 ; 11) \\
\mathrm{f}(\mathrm{O} 1)\end{array}$ & $\begin{array}{c}(5 ; 0-6 ; 0) \\
\mathrm{f}(\mathrm{O} 2)\end{array}$ & $\mathrm{LL}$ & Sig. \\
\hline Of. Ap. & 100 & 70 & 1,07 & $+0,302$ \\
Of. Ap. with Alerter & 18 & 9 & 1,55 & $+0,213$ \\
A Promise & 11 & 13 & 0,79 & $-0,374$ \\
Intensified Of. Ap. & 8 & 8 & 0,15 & 0,695 \\
Forgiveness & 7 & -- & -- & -- \\
Repair & 7 & 14 & 3,96 & $-0,047$ \\
$\ldots$ & & & & \\
$\ldots$ & & & & \\
Total & 157 & 129 & & \\
\hline
\end{tabular}

$\mathrm{f}=\mathrm{raw}$ frequency of each category

O1: Observed frequency 1

O2: Observed frequency 2

+ indicates overuse in $\mathrm{O} 1$ relative to $\mathrm{O} 2$

-indicates underuse in $\mathrm{O} 1$ relative to $\mathrm{O} 2$ 
As is clear in Table 7 above, there has been an overwhelming preference of the sub-category of IFIDs, an offer of apology, in both age groups; having higher usage rate in the younger group, which showed that they mostly preferred to apologize in a more explicit way. It is expressed in the form of "özür dilerim" (I apologize) which is the most formulaic form of apology in Turkish while in the other languages such as English "I'm sorry" was found to be the most routinized form which falls in the category of an expression of regret (see Owen, 1983).

Examination of the Turkish adult literature yielded an outcome which echoes children's patterns in that both Hatipoğlu (2003) and Nazlı (2013) reported a marked preference of an offer of apology by Turkish native speakers among the other categories. This shows that similar to adults, Turkish children's apologies are formulaic in semantic structure.

Additionally, the calculation of the overall usage of IFIDs -together with all the subcategories- revealed an overwhelmingly higher usage rate than the other strategies in the list for both groups. As expected, this finding completely matches with children's preferences in various languages like Kurdish and Persian (Sadeghi, 2013), Mandarin Chinese (Chang, 2016), and Hebrew (Kampf \& Blum-Kulka, 2007).

Regarded as one way of reinforcing apologies, intensification was observed to be used only within the sub-category an offer of apology. Namely, children preferred to use the other sub-categories of IFIDs like a request for forgiveness or an expression of regret in their basic forms; not producing such forms as "çok affedersiniz" or "çok üzgünüm” (I'm so/very sorry). On the contrary, Turkish university students were found to intensify all the three subcategories although much of the intensification was actualized within an offer of apology (see Hatipoğlu, 2003).

Another interesting finding that is worth mentioning is related to the use of offer of repair. The older group was observed to produce more repairs than the younger group when all the usage in single, two- and three-strategy combinations was evaluated. This echoes Chang's (2016) outcome which pointed at a gradual increase in the use of this strategy with increasing age.

As Fraser (1981) states, in general, speakers prefer to use a combination of a number of strategies for apologizing rather than a single strategy. Similarly, both older and younger children in the present study formed combinations that consisted of two and three strategies. The types of strategies that are mostly utilized are displayed in Table 8 and 9 below. 
Table 8. Observed frequencies and LL ratios of two-strategy combinations across the two age groups

\begin{tabular}{lcccc}
\hline Combinations & $(4 ; 0-4 ; 11)$ & $(5 ; 0-6 ; 0)$ & LL & Sig. \\
& $\mathrm{f}(\mathrm{O} 1)$ & $\mathrm{f}(\mathrm{O} 2)$ & & \\
\hline Of. Ap.+Promise & 97 & 75 & 10,64 & $\mathbf{+ 0 , 0 0 1}$ \\
Of. Ap.+Repair & 17 & 46 & 7,78 & $\mathbf{- 0 , 0 0 5}$ \\
Of. Ap.+Lack of Intent & 16 & 29 & 1,32 & $-0,250$ \\
Of. Ap. with Alerter + & 16 & 16 & 0,47 & $+0,495$ \\
Promise & 12 & 22 & 1,06 & $-0,302$ \\
Of. Ap.+Forgiveness & & & & \\
$\ldots$ & & & & \\
$\ldots$ & 194 & 247 & & \\
Total & &
\end{tabular}

$\mathrm{f}=$ raw frequency of each category

O1: Observed frequency 1

$\mathrm{O} 2$ : Observed frequency 2

+ indicates overuse in $\mathrm{O} 1$ relative to $\mathrm{O} 2$

-indicates underuse in $\mathrm{O} 1$ relative to $\mathrm{O} 2$

Table 9. Observed Frequencies and LL Ratios of Three-strategy Combinations across the Two Age Groups

\begin{tabular}{lcccc}
\hline Combinations & $\begin{array}{c}(4 ; 0-4 ; 11) \\
\mathrm{f}(\mathrm{O} 1)\end{array}$ & $\begin{array}{c}(5 ; 0-6 ; 0) \\
\mathrm{f}(\mathrm{O} 2)\end{array}$ & LL & Sig. \\
\hline Of. Ap.+Promise+ Repair & 12 & 17 & 0,17 & $-0,678$ \\
Of. Ap.+Downgrader +Repair & 3 & -- & -- & -- \\
Of. Ap.+Forgiveness+Repair & 3 & -- & -- & -- \\
Of. Ap.+Promise+Minimizing & 2 & -- & -- & -- \\
Of. Ap.+Accepting the & 2 & -- & -- & -- \\
Blame+Lack of Intent & 2 & & & \\
Of. Ap.+Lack of Intent+Repair & & 7 & 2,06 & $-0,151$ \\
$\ldots$ & & & & \\
$\ldots$ & & & & \\
Total & 33 & 40 & & \\
\hline
\end{tabular}

$\mathrm{f}=$ raw frequency of each category

O1: Observed frequency 1

O2: Observed frequency 2

+ indicates overuse in $\mathrm{O} 1$ relative to $\mathrm{O} 2$

-indicates underuse in $\mathrm{O} 1$ relative to $\mathrm{O} 2$ 
As seen in Table 8 and 9 above, nearly all two- and three-strategy combinations included an offer of apology in both younger and older group. The data regarding two-strategy combinations did not yield much difference in the number of categories produced by the two groups. However, significant differences were found in the usage rates of certain combinations: these are an offer of apology + a promise of forbearance, which had higher use in the younger group $(\mathrm{p}<.01)$ and an offer of apology + offer of repair which was preferred significantly more in the older group $(\mathrm{p}<.01)$. Similarly, the data indicated no difference between the groups in terms of the variety incorporated into the categories of threestrategy combinations. In general, there was an overwhelming tendency to combine an offer of apology with a promise and an offer of repair in both age groups.

\subsection{Effect of Gender on Children's Apology Patterns}

In order to explore potential gender differences on children's manner of apologizing, the overall data which consists of 800 responses in total (from 8 scenarios) were classified into two groups as male and female productions. As aforesaid in the methodology section, there are totally 51 female children, who provided totally 408 responses. On the other hand, the number of male participants is 49 , which yielded totally 392 responses. Firstly, the results of the analysis with regard to the complexity of patterns are shown in Table 10 below with the total rates of use and significance values of each category.

Table 10. Observed frequencies and LL ratios of total strategies based on gender

\begin{tabular}{lcrccc}
\hline $\begin{array}{l}\text { Complexity of } \\
\text { patterns }\end{array}$ & Male & Female & Total & LL & Sig. \\
& $\mathrm{f}(\mathrm{O} 1)$ & $\mathrm{f}(\mathrm{O} 2)$ & $\mathrm{f}$ & & \\
\hline $\begin{array}{l}\text { Single Strategy } \\
\text { Two-strategy }\end{array}$ & 152 & 134 & 286 & 1,97 & $+0,161$ \\
$\begin{array}{l}\text { Combinations } \\
\text { Three-strategy }\end{array}$ & 208 & 233 & 441 & 0,59 & $-0,441$ \\
$\begin{array}{l}\text { Combinations } \\
\text { Total }\end{array}$ & 32 & 41 & 73 & 0,78 & $-0,377$ \\
\hline
\end{tabular}

$\mathrm{f}=$ raw frequency of each category

O1: Observed frequency 1

O2: Observed frequency 2

+ indicates overuse in $\mathrm{O} 1$ relative to $\mathrm{O} 2$

-indicates underuse in $\mathrm{O} 1$ relative to $\mathrm{O} 2$

As can be clearly displayed in the table above, there are differences in the frequency rates of single and multiple strategies: the use of both two-and three- 
strategy combinations was higher in the female group compared to males although the difference was not found significant. Furthermore, both groups were prone to combine two strategies to redress their transgressions.

In parallel to our finding, Chang (2016) pointed at males' mostly using simpler patterns (single or two-strategy combinations) compared to their female counterparts with a higher number of complex patterns (three-, four- and fivestrategy combinations). It appears that females are more concerned about the language they use to beg for forgiveness may be because they are more inclined to resolve conflicts (see Sheldon, 1990). There are also findings that indicate just the reverse (see Cook-Gumperz \& Szymanski, 2001) or no significant difference (e.g., Ladegaard, 2004; Greif \& Gleason, 1980; Schleien et al., 2010). Therefore, the gender issue necessitates further scrutiny to reach a consensus. The results related to the mostly utilized single strategies are given in the following table:

Table 11. Observed frequencies and LL ratios of basic strategies based on gender

\begin{tabular}{lcccc}
\hline Strategies & $\begin{array}{c}\text { Male } \\
\mathrm{f}(\mathrm{O} 1)\end{array}$ & $\begin{array}{c}\text { Female } \\
\mathrm{f}(\mathrm{O})\end{array}$ & LL & Sig. \\
\hline Of. Ap & 89 & 81 & 0,07 & $-0,798$ \\
Of. Ap with Alerter & 18 & 9 & 1,98 & $+0,160$ \\
Repair & 12 & 9 & 0,12 & $+0,726$ \\
A Promise & 11 & 13 & 0,54 & $-0,462$ \\
Intensified apology & 8 & 8 & 0,07 & $-0,789$ \\
$\ldots$ & & & & \\
$\ldots$ & & & & \\
Total & 152 & 134 & & \\
\hline
\end{tabular}

$\mathrm{f}=$ raw frequency of each category

O1: Observed frequency 1

O2: Observed frequency 2

+ indicates overuse in $\mathrm{O} 1$ relative to $\mathrm{O} 2$

-indicates underuse in $\mathrm{O} 1$ relative to $\mathrm{O} 2$

As seen above, the findings revealed both groups' utilizing nearly the same range of strategies. Although the frequency of certain strategies pointed at variations across the two groups, the difference was far from being significant. This finding is supportive of the outcomes of other relevant studies (e.g., Holmes, 1990; Meier, 1996). Together with its sub-categories, the main category IFIDs was found to be the most preferred strategy in both male and female group as in several other studies (e.g., Owen, 1983; Holmes, 1990). Types of mostly used two- and three-strategy combinations are displayed in Table 12 and 13, respectively. 
Table 12. Observed frequencies and LL ratios of two-strategy combinations based on gender

\begin{tabular}{lcccc}
\hline Combinations & $\begin{array}{c}\text { M } \\
\mathrm{f}(\mathrm{O} 1)\end{array}$ & $\begin{array}{c}\mathrm{F} \\
\mathrm{f}(\mathrm{O} 2)\end{array}$ & LL & Sig. \\
\hline Of. Ap +Promise & 77 & 95 & 0,40 & $-0,528$ \\
Of. Ap +Offer of Repair & 40 & 23 & 6,78 & $+0,009$ \\
Of. Ap +Lack of Intent & 29 & 16 & 5,43 & $+0,020$ \\
Of. Ap +Forgiveness & 14 & 20 & 0,49 & $-0,483$ \\
$\ldots$ & & & & \\
$\ldots$ & & & & \\
Total & 208 & 233 & & \\
\hline
\end{tabular}

$\mathrm{f}=$ raw frequency of each category

O1: Observed frequency 1

O2: Observed frequency 2

+ indicates overuse in $\mathrm{O} 1$ relative to $\mathrm{O} 2$

-indicates underuse in $\mathrm{O} 1$ relative to $\mathrm{O} 2$

Table 13. Observed Frequencies and LL Ratios of Three-strategy Combinations Based on Gender

\begin{tabular}{lcccc}
\hline Combinations & $\begin{array}{c}\mathrm{M} \\
\mathrm{f}(\mathrm{O} 1)\end{array}$ & $\begin{array}{c}\mathrm{F} \\
\mathrm{f}(\mathrm{O} 2)\end{array}$ & $\mathrm{LL}$ & Sig. \\
\hline Of. Ap +A Promise+Repair & 16 & 13 & 1,50 & $+0,221$ \\
Of. Ap +Lack of Intent+Repair & 3 & 6 & 0,41 & $-0,520$ \\
Of. Ap.+Lack of Intent+Forgiveness & 3 & 2 & 0,53 & $+0,468$ \\
$\ldots$ & & & & \\
$\ldots$ & 32 & 41 & & \\
Total & 32 & & \\
\hline
\end{tabular}

Table 12 and 13 show that mostly favored categories indicated a similar sequence in both groups; female and male choices were shaped around similar combinations. Among the others, both groups were more inclined to combine an explicit form of apology with a promise in their two-strategy combinations. Although the usage was higher among females the difference was not statistically verified. Concerning three-strategy combinations, The category of an offer of apology+a promise +offer of repair was the most preferred combination in both groups. 


\subsection{Effect of Contextual Factors on Apology Realization Patterns: Severity of the Offence}

Holmes (1990, p. 156) points out that there is a "relationship between the complexity of the apology and the weightiness of the offence which elicited it". Accordingly, the gravity of the offence is a predictive factor that plays a role in determining how elaborate the apology pattern will be. Considering this, the present study aimed to test children's socio-pragmatic skills evidenced by sensitivity to contextual features of the situations and their ability to adjust their speech accordingly. Complexity of strategies can be traced in Table 14 below.

Table 14. Observed frequencies and LL ratios of total strategies based on severity of the offence

\begin{tabular}{lcccc}
\hline Complexity of Patterns & High & Low & LL & Sig. \\
& $\mathrm{f}$ & $\mathrm{f}$ & & \\
\hline Single Strategy & 95 & 127 & 4,63 & $\mathbf{- 0 , 0 3 1}$ \\
$\begin{array}{l}\text { Two-strategy } \\
\text { Combinations }\end{array}$ & 163 & 150 & 0,54 & $+0,462$ \\
$\begin{array}{l}\text { Three-strategy } \\
\text { Combinations }\end{array}$ & 42 & 23 & 5,64 & $\mathbf{+ 0 , 0 1 8}$ \\
Total & & & & \\
\hline
\end{tabular}

$\mathrm{f}=$ raw frequency of each category

O1: Observed frequency 1

O2: Observed frequency 2

+ indicates overuse in $\mathrm{O} 1$ relative to $\mathrm{O} 2$

-indicates underuse in $\mathrm{O} 1$ relative to $\mathrm{O} 2$

The results displayed in Table 14 revealed a statistically significant difference $(\mathrm{p}<.05)$ between the frequencies of single strategy usage; higher for the breaches with low severity, which implies that children possibly thought that using strategies as standalone was sufficient to ask for forgiveness following minor offences. In parallel, the use of three-strategy combinations was significantly $(p<.05)$ higher for more serious breaches. This shows that children could distinguish between serious and minor offences and tailored their realization patterns accordingly. This finding is supportive of Fraser's (1981) argument that serious harms necessitate using more heavy and comprehensive remedial acts, which proved to be the case in most studies as well (see Holmes, 1990; MarquezReiter, 2000).

This demonstrates that preschool-aged children take notice of the seriousness degree of an offence since they mostly preferred multiple-strategies to mitigate serious breaches. Similarly, in their study, Gleason and Perlmann (1985) found that there was a gradually developing sensitivity to the requirements of a certain 
situation and children's ability to use language to fulfil these essentials develops concomitantly. Most used strategy types are presented in Table 15 below.

Table 15. Observed frequencies and LL ratios of basic strategies based on the severity of the offence

\begin{tabular}{lcccc}
\hline Strategy type & $\begin{array}{c}\text { High } \\
\mathrm{f}(\mathrm{O} 1)\end{array}$ & $\begin{array}{c}\text { Low } \\
\mathrm{f}(\mathrm{O} 2)\end{array}$ & LL & Sig. \\
\hline Of. Ap. & 50 & 69 & 0,03 & $-0,864$ \\
Repair & 16 & 5 & 9,69 & $\mathbf{+ 0 , 0 0 2}$ \\
Of. Ap.with Alerter & 14 & 11 & 1,76 & $+0,185$ \\
Intensified Of. Ap. & 9 & 6 & 1,79 & $+0,181$ \\
Regret & 3 & 4 & 0,00 & $+0,997$ \\
Promise & 1 & 17 & 12,96 & $\mathbf{- 0 , 0 0 0}$ \\
$\ldots$ & & & & \\
Total & 95 & 127 & & \\
\hline
\end{tabular}

When the strategy choices of the children were investigated, it was observed that in contrast to Schlenker and Darby (1981), IFIDs in total emerged to be the most favoured strategy regardless of the seriousness degree of the breach without a significant difference. On the other hand, offering repair was used significantly more for serious offences $(\mathrm{p}<.01)$ and interestingly, children were found to give a promise for non-occurrence of a future action significantly more for minor offences $(\mathrm{p}<.001)$. This may imply that children considered giving promises sufficient for mitigating minor misdeeds while the same was not considered as effective enough to compensate for the damage they've caused in more serious predicaments.

In terms of intensification, our finding stands in contrast to Olshtain and Cohen (1983) who argue that highly intensified apologies like "I'm terribly sorry" are provided for a more serious offence whereas "I'm sorry" is offered as a consequence of minor transgressions. In the present study, intensified apologies were employed for both serious and minor offences although the usage was found higher for the former.

\section{Conclusion}

With respect to children's metapragmatic knowledge related to the use of apologies, we found that children in both age groups are cognizant of the function of apologies as remedial acts as they were adept at distinguishing apologies among many types of speech acts used as controls in the ODCT. This finding provides evidence to the claim pointed out by many scholars in the field (e.g., Darby \& Schlenker, 1982; Smith et al., 2010) that even four-year-old children are aware that an apology is required when a social norm is violated. 
Concerning children's realisation patterns, the analysis of the overall productions of the two age groups exhibited children's tendency to use mostly combination of strategies rather than using them as standalone similar to adultmanner (see Demeter, 2006; Vollmer \& Olshtain, 1989). The analysis of the repertoire of strategies did not result in any age effect apart from differences in the frequency rates of certain categories utilized higher either by younger or older group. In addition, observation of the types of basic strategies indicated similarities with teenage or adult-usage in other languages in general and in Turkish in particular but with different sequence and proportions.

Turning to the effect of gender, no significant difference was observed in terms of the complexity of patterns in the corpus of male and female children although multiple strategy usage was higher in the latter. Observation of strategy types did not also yield any difference in range, but slight differences were evident in the sequence of the most popular strategies in the two groups.

Finally, noticeable differences were observed between the responses provided for the transgressions with high and low severity: while the predicaments with low severity were mitigated by employing significantly higher number of single strategies, offences with severe consequences were alleviated with significantly higher usage of multiple strategies. Therefore, it may be possible to state that preschool-aged children can classify incidents depending on their degree of severity.

\section{References}

Babanoğlu, P. M. (2014). A corpus-based study on the use of pragmatic markers as speech-like features in Turkish EFL learners' argumentative essays. Procedia-Social and Behavioral Sciences 136, 186-193.

Can, C., \& Yakut, İ. (2018). A corpus-driven approach to I think as a pragmatic marker in native and non-native discourse. International Journal of Language Academy, 6(5), 210-229.

Bardovi-Harlig, K. \& Hartford, B. S. (2005). Interlanguage pragmatics: Exploring institutional talk. Mahwah, NJ: Erlbaum.

Blum-Kulka, S. (1997). Dinner talk: Cultural patterns of sociability and socialization in family discourse. Mahwah, NJ: Lawrence Erlbaum.

Blum-Kulka, S., House, J., \& Kasper, G. (1989). Cross-cultural pragmatics: Requests and apologies. Norwood, NJ: Ablex Pub.

Blum-Kulka, S., \& Olshtain, E. (1984). Requests and apologies: A cross-cultural study of speech act realization patterns (CCSARP). Applied Linguistics, 5(3), 196-213.

Brown, P., \& Levinson, S. C. (1987). Politeness: Some universals in language usage. Cambridge: Cambridge University Press.

Cameron-Faulkner, T. (2014). Pragmatic development: trends in language acquisition research. In D. Matthews (Ed.), Pragmatic development in first language acquisition (pp.37-52). Amsterdam: John Benjamins. 
Chang, Y. (2016). Apologizing in Mandarin Chinese: A study on developmental patterns. Concentric: Studies in Linguistics, 42(1), 73-101.

Chang, Y. (2018). The effect of interlocutor's social status on the use of apology strategies: Across-sectional study. Concentric: Studies in Linguistics, 44(1), 89-122.

Cohen, A. D. (1996). Developing the ability to perform speech acts. Studies in Second Language Acquisition, 18(2), 253-267.

Cohen, R. (2004). Apology and reconciliation in international relations. In B. Yaacov (Ed.), From conflict resolution to reconciliation (pp. 177-195). Oxford, New York: Oxford University Press.

Cordella-Masini, M. (1989). Apologizing: a cross-cultural study in Chilean Spanish and Australian English. Master's thesis, Australian National University. Retrieved February 14, 2017 from http://erl.canberra.edu.au./public/adt-AUC20060907.102205

Cook-Gumperz, J., \& Szymanski, M. (2001). Classroom "families": Cooperating or competing-girls' and boys' interactional styles in a bilingual classroom. Research on Language and Social Interaction,34(1), 107-130.

Çetinavcı, U. R. (2012). Apologizing in Turkish language: An intracultural and intercultural exploratory study. Contemporary Online Language Education Journal, $1,72-104$.

Darby, B. W., \&Schlenker, B.R. (1982). Children's reactions to apologies. Journal of Personality and Social Psychology, 43(4), 742-753.

Demeter, G. (2006). A Pragmatic study of apology strategies in Romanian. Master thesis, North University, Romania. Retrieved July 28, 2016 from http://digital.library.okstate.edu/etd/umi-okstate-1727.pdf

Dunning, T. (1993). Accurate methods for the statistics of surprise and coincidence. Computational Linguistics 19(1), 61-74.

Ely, R., \& Gleason, J. B. (2006). I'm sorry I said that: apologies in young children's discourse. Journal of Child Language, 33(3), 599-620.

Fraser, B. (1981). On apologizing. In Florian Coulmas (Ed.), Volume 2: Conversational routine: Explorations in standardized communication situations and prepatterned speech (pp. 259-273). The Netherlands: Mouton Publishers.

Gleason, J. B., \& Perlmann, L. (1985). Acquiring social variation in speech. In H. Giles \& R. StClair (Eds.), Recent advances in language, communication, and social psychology (pp. 86-111). London: Lawrence Erlbaum.

Greif, E. B., \& Gleason, J. B. (1980). Hi, thanks, and goodbye: More routine information. Language in Society, 9, 159-166.

Hatipoğlu, Ç. (2003). Culture, gender, and politeness: Apologies in Turkish and British English. Unpublished doctoral thesis, the University of the West of England, Bristol.

Holmes, J. (1990). Apologies in New Zealand English. Language in Society, 19(2), 155199.

Kampf, Z., \& Blum-Kulka, S. (2007). Do children apologize to each other? Apology events in young Israeli peer discourse. Journal of Politeness Research. Language, Behaviour, Culture, 3(1), 11-37.

Kasper, G. (2000). Data Collection in Pragmatics Research. In H. Spencer-Oatey (Ed.), Culturally speaking: Managing rapport through talk across cultures (pp. 316-341). New York: Continuum. 
Küntay, A.C., Nakamura, K., \& Ateş, B. Ş. (2014). Cross-linguistic and cross-cultural approaches to pragmatic development. In D. Matthews (Ed.), Pragmatic development in first language acquisition (pp. 317-342). Amsterdam: John Benjamins.

Ladegaard, H. J. (2004). Politeness in young children's speech: context, peer group influence, and pragmatic competence. Journal of Pragmatics, 36, 2003-2022.

Marquez-Reiter, R. (1999). 'Polite and 'impolite requests and apologies in British English and Uruguayan Spanish: A comparative study. Doctoral thesis, Boston Spa, Wetherby, West Yorkshire. Retrieved August 13, 2017 from http://etheses.whiterose.ac.uk/14780/1/301017 vol1.pdf

Marquez Reiter, R. (2000). Linguistic politeness in Britain and Uruguay: A contrastive study of requests and apologise. Amsterdam: John Benjamins.

McEnery, T.,Xiao, R., \&Tono, Y. (2006). Corpus-based language studies: An advance resource book. New York: Routledge.

Meier, A.J. (2004). Conflict and the power of apologies. PhiN, 30, 1-17.

Nazlı, E.H. (2013). Türkçe özür ifadeleri üzerine toplumdilbilimsel bir inceleme. Unpublished master's thesis, Dicle University, Diyarbakır.

Ninio, A., \& Snow, C. E. (1996). Pragmatic development: Essays in developmental science. CO, US: Westview Press.

Olshtain, E. (1989). Apologies across languages. In S. Blum-Kulka, J. House \& G. Kasper (Eds.), Cross-cultural pragmatics: Requests and apologies (pp.155- 173). New Jersey: Ablex.

Olshtain, E. \& Cohen, A. D. (1983). Apology: A speech act set. In N. Wolfson \& E. Judd (Eds.), Sociolinguistics and language acquisition (pp.18-35). Rowley, Mass: Newbury House.

Owen, M. (1983). Apologies and remedial interchanges: A study of language use in social interaction. Berlin \& New York: Mouton Publishers.

Özyıldırım, I. (2010). The level of directness in Turkish apology forms in relation to the level of education. Journal of Faculty of Letters, 27(1), 179-201.

Rose, K. R. (2000). An exploratory cross-sectional study of interlanguage pragmatic development. Studies in Second Language Acquisition, 22, $27-67$.

Rose, K. R. (2009). Interlanguage pragmatic development in Hong Kong, phase 2. Journal of Pragmatics, 41, 2345-2364.

Sackin, S. \& Thelen, E. (1984). An ecological study of peaceful associative outcomes to conflict in preschool children. Child Development, 55(3), 1098-1102.

Sadeghi, M.R. (2013). A cross-linguistic investigation of language apology speech act: a case study of Persian and Kurdish children. Journal of Languages and Culture, 4(3), 30-38.

Schieffelin, B.B., \&Ochs, E. (1986). Language socialization. Annual Reviews, 15, $163-$ 191.

Schleien, S., Ross, H., \& Ross, M. (2010). Young children's apologies to their siblings. Social Development, 19(1), 170-186.

Schlenker, B. R. \& Darby, B. W. (1981). The use of apologies in social predicaments. Social Psychology Quarterly, 44(3), 271-278.

Sheldon, A. (1990). Pickle fights: Gendered talk in preschool disputes. Discourse Processes: special issue on language and gender, 13(1), 5-31. 
Smith, C.E. (2009). He wished he didn't do it: Children's thinking about transgression and apology. Unpublished doctoral thesis, Harvard University, Massachusetts.

Smith, C. E., Chen, D., \&Harris, P. L., (2010). When the happy victimizer says sorry: children's understanding of apology and emotion. British Journal of Developmental Psychology, 28, 727-746.

Snow, C. E., Pan, B. A., Bailey, A., \& Herman, J. (1996). Learning how to say what one means: a longitudinal study of children's speech act use. Social Development, 5(1), 56-70.

Walliman, N. (2011). Research methods: The basics. New York: Routledge.

Vollmer, H. J., \& Olshtain, E. (1989). The language of apology in German. In S. BlumKulka, J.House \& G. Kasper (Eds.), Cross-cultural pragmatics: Requests and apologies (pp. 197-218). New Jersey: Ablex. 